\title{
PKK Terrorism in Turkey
}

\author{
Hanefi Yazıcı \\ Department of Political Sciences and International Relations, Faculty of Economics and Administration Sciences, \\ Bandırma Onyedi Eylül University, Balıkesir, Turkey \\ Email: hyazici@hotmail.com
}

Received 31 May 2016; accepted 18 July 2016; published 21 July 2016

Copyright (C) 2016 by author and Scientific Research Publishing Inc.

This work is licensed under the Creative Commons Attribution International License (CC BY). http://creativecommons.org/licenses/by/4.0/

(c) (i) Open Access

\section{Abstract}

This paper examines the profile of the PKK (Kurdish Workers' Party) and distinguishes Kurdish issue from terrorism in Turkey. PKK's profile has changed depending on Turkey's internal politics under AK Party governments as well as the changing international environment particularly in Syria and demands a federation of Kurds that is independent Kurdistan in southeastern Turkey. The first part of this article addresses the objectives of the PKK and its violence and terrorism in pursuit of Kurdish secession from the Republic of Turkey leading to thousands of military and civilian deaths over the past decades. The second part assesses the problem focusing on whether PKK truly represents Kurds in Turkey. The third section tries to answer the question of who provides the logistical and financial support for PKK since it is still controversial whether the US and the EU both classify the PKK as a terrorist organization ingenuously. The last section evaluates political solution to the PKK problem, which is now being voiced in both Turkey and Western countries particularly in US.

\section{Keywords}

Kurdish, Rebellion, Republic of Turkey, US, EU, PKK

\section{Introduction}

In the late nineteenth and twentieth centuries, the Kurds of Turkey have agitated for their local rights so many times. Today, because of the international developments including the democratization and human rights, the Kurds of Turkey raise political expectations in the context of a modern world of nation states. Turkey's Kurds are the largest ethnicgroup in republican Turkey and have repeatedly challenged republican nation-state policies. The Kurds have been divided among the states of Turkey, Iran, Iraq, and Syria. They don't have their own states and nearly half of them live in the eastern part of Turkey.

It is obvious that the Kurdish problem in Turkey can be solved by political and democratic reforms. First, 
Turkish army has been trying to solve the PKK problem for a few decades by shooting militants on behalf of the Republic of Turkey. Second, so far no politicians have acted courageously to solve the problem politically. Next, it is impossible to prevent terrorism only by shooting militants without political solution. It is well known that we need to drain the swamp instead of swatting mosquitoes. Moreover, it is the first time that a government in Turkey tries to solve the PKK problem politically acting bravely and although there have been hundreds of martyrs Turkish people supported the political decision of government because despite the PKK terrorism, the Kurds and Turks have been living together in peace in Turkey for a long time and it is clear that day by day PKK is losing its authority on Kurdish people just after the solution process that is Kurdish-Turkish peace process. Unfortunately, even though Turkish government agreed to a ceasefire to get PKK militants to disarm, the ongoing peace process ended with the resumption of violence by PKK in 2015.

\section{Spread of Nationalism and the Committee of Union and Progress (CUP)}

Spread of nationalism was successful among many ethnic groups of the Ottoman Empire but Kurds were not as successful as other ethnic groups. Turkish nationalism was developed by the Young Turk movement. The Young Turk movement was favoring reformation of the administration of the Ottoman Empire. The movement was against the absolute monarchy of the Ottoman Sultan and they established the second constitutional era in 1908 (Hanioğlu, 1995: pp. 200-205). Young Turks were known as the members of Ottoman society who were modernist and opposed to the status quo. Today, most of Turkish people glorify the Young Turks since they initiated the process of liberalization of modern Turkey (Hanioğlu, 1995: pp. 206-212). They became an organized movement with the Committee of Union and Progress (CUP).

As an ideology, the Young Turks adopted liberal ideas and their goal was the transformation of the Ottoman society replacing religion with science therefore they were accused of changing Islam into a new religion. Auguste Comte had an effect on the Young Turks and they preferred Positivism as a religion of science and ignored religion. Furthermore, their ideology constituted the foundations for Ataturk's revolutions which turned Turkey into a modern state (Hanioğlu, 2001: pp. 210-220). Finally, the effect of Young Turks shaped Republic of Turkey and the new regime was based on positivist ideology.

On the other hand, Feroz Ahmad gives the exact date of 1908 as the emergence of Turkish nationalism. He also gives detail information about the establishment of the Committee of Union and Progress (CUP). According to Ahmad, the Unionists opposed to the ideology of Ottomanism and their aim was to establish a new secular modern state. In the eyes of Ahmad the Unionists were confident that they could transform and rescue the empire if only they were given the opportunity to govern, even indirectly. They were aware that Ottoman society was too conservative to accept them as rulers.

Feroz Ahmad claims that in the transitional period which began in July 1908, there was a latent struggle for power between the sultan, supported by conservatives and reactionaries, the high bureaucrats, supported by the Liberals, and the Unionists who relied on their organizational strength in the army (Ahmad, 1993: pp. 34-35). Kurdish nationalism was not successful because Ottoman Kurds remained loyal to the Ottoman Empire. Tribal loyalty was very important figure for the majority of Kurds and it was stronger than national loyalty. So this affected and weakened the Kurdish national identity. Ottoman Kurds fought on the side of Ottoman Turks in the wars although the Treaty of Sevres gave a chance for an independent Kurdish state in the eastern Turkey and they continued to fight with Turkish people against foreign invaders in Anatolia. The fight on the side of Ottoman Turks showed that religion was one of the most important figures for Kurdish identity.

After Mustafa Kemal declared that he was going to establish republican Turkey, which was going to be a nation state and will be based on Turkish national identity. Some Kurdish people in Turkey preferred to live as Turkish citizens instead rebelling against the new regime (Ahmad \& Yavuz, 2013). Not only religious Kurds but also many radical religious Turkish people were against the new secular republican nation state. There is a consensus among historians about the reactions of conservatives who were still supporting old regime and against new secular regime. In Making of Modern Turkey, Feroz Ahmad states that the conservatives did not abandon the struggle against the Kemalists. Finally, the Grand National Assembly deposed the caliph, abolished the Caliphate, and banished all members of the house of Osman from Turkey on 3 March 1924.The abolition of the Caliphate was the prelude to the program of radical secularism (Ahmad, 1993: p. 54).

According to Mcdowall, the date 3 March 1924 is a turning point for the new modern state as Mustafa Kemal broke the links of old regime to make a secular modern state which not only provoked Turkish but also Kurdish 
conservatives. Mcdowall claims that the caliphate was the last ideological tie between the Kurds and Turks and he states that by stripping abolishing religious institutions, Mustafa Kemal made The Kurds enemies (Mcdowall, 2005: p. 192).

\section{The Kurds in Turkey}

The new regime quickly accepted secularism with Western values. The state also under the Kemalist regime described the meaning of the Turkish as ethnic. Therefore Kurds officially became Turkish citizen according to the 1924 constitution. Kurdish people continued to live in Turkey as Turkish so they were not threat for the new modern nation state (Gunter, 1990). In the past, Islam played an important role among Turks and Kurds to feel like brothers. But the new regime abolished religious buildings covering the state by Western secular system. Surely, it was easy to recognize that Kurdish sheikhs, like Sheikh Said, provoked the streets to revolt against the new secular state, republican Turkey.

The abolition of the Sultanate (in 1922) and the Caliphate (in 1924) challenged the role of the aghast as secular leaders, and of the sheikhs as religious ones, particularly since the new Republic became secular (Kreyenbroek \& Sperl, 1992: p. 18). The idea of autonomy for the Kurds in 1923 was never discussed publicly. Therefore, there were repeated revolts by the Kurds against the new order, in the 1920s and 1930s and there was not national unity among the Kurds. The government executed the leaders, and deported the inhabitants out of the area. Kurdish parts of Turkey have remained under military control so far. And the clashes between the civil people and soldiers continued for a long time (Russell, 2012).

It can be argued that the Sheikh Said rebellion was both a religious and tribal and it was a revolt against the secularist new regime and was also first steps of a local movement of Kurdish nationalism. The Sheikh Said rebellion is a turning point in the history of modern Turkey. After this rebellion it became easy for the state to make reforms to establish a modern secular state (Yildiz, 2005). The new government wanted to solve the Kurdish problem by sending many of them to the Western cities of the country willing to change the demographic position of the country to assimilate the Kurds. It was clear that the state realized the reason of the resistance of the Kurds as the tribal connections. Unfortunately, the state saw the Kurdish resistance to the state power as the resistance of brigands. When the state of Turkey tried reconstituting the Kurdish resistance as the resistance of bandits, the discourse of the state removed the Kurdish resistance. It is not surprising to see that up to date the word of banditry has become a popular discourse used for many Kurdish movements by the state.

\section{The Sheikh Said, Ararat and Dersim Rebellions}

Today Turkey is trying to solve the PKK problem which remained unsolved for a few decades without disturbing Kurdish people in the eastern part of the country. Surely it is not easy to distinguish local people in the region as many PKK militants live near the villages. It is controversial whether PKK fight for the political rights of Kurdish people in the eastern part of Turkey. It was the first time that a Kurdish nationalist group used weapons on behalf of Kurdish people particularly in the early 1980s. In the past the armed Kurdish groups were not nationalist instead they were religious and tribal.

The first armed Kurdish rebellion against secular republican Turkey took place in 1925. The Sheikh Said rebellion of 1925 was a tribal and religious movement (Olson, 2000: p. 69). The new regime made reforms for the abolition of the Caliphate and the limitation of public role of Islam to ensure ethnic homogenization of Turkey's population. In 1925 under the leadership of Sheikh Said, the Kurdish tribes rebelled against republican Turkey. It was a religious and ethnic revolt to react against the secular Turkish state established by Mustafa Kemal who named the national identity of the state as Turkish. Turkish armed forces succeeded in quickly suppressing the rebellion. The Turkish government took violent policy measures to suppress Kurdish rebellions and also continued modern secular program.

The Sheikh Said rebellion of 1925, the Ararat revolt of 1930 and the Dersim rebellion of 1937-38 were significant developments in the history of modern Turkey. Olson claims that these rebellions contributed to the development of Turkey's air force (TAF) which was to be used as an instrument to control, suppress and eradicate Kurdish nationalism (Olson, 2000: p. 68). He argues in his article that by the development of the TAF from 1925 onward played an important role in the ability of the Turkish state to further consolidate its ideology of Turkish nationalism vis-a-vis that of Kurdish nationalism during the inter-war period.

On the other hand, Erik Zurcher writes in his book, Turkey, a Modern History, that the Kurdish nationalists 
were aware that they were going to deal with great problems as Mustafa Kemal was going to transform the structure of the new state from religious and multiethnic empire to a modern secular nation state. Zurcher shows in his book that although the Kurds had some rights under the Treaty of Sevres they did not listen to the British agents to revolt against Turkey and he gives some detail information about the Sheikh Said rebellion (Zurcher, 1993: p. 170). By and large, the Kurds supported the resistance movement and there were Kurdish representatives in Erzurum and Sivas committees, despite the efforts of British agents to influence them and despite the fact that they were granted autonomy under the Treaty of Sevres.

Zurcher also reminds that within the new borders of the republic nearly 20 percent of the population was Kurdish, but they were not mentioned in the Peace Treaty of Lausanne and Mustafa Kemal never remembered the promises of autonomy under the Treaty of Sevres, during the independence struggle. Zurcher states that relations between the Kurds and the predominantly Turkish republican government deteriorated in 1924. He considers that the abolition of the caliphate removed a vital religious symbol that bound the two communities together. On the other hand, just after Sheikh Saidrebellion several Kurdish groups did not obey the new regime and rejected to live under the control of the state and established illegal committees to struggle against the new government (White, 2015).

\section{Kurdish-Turkish Peace Process and PKK Rebellion}

As well known in Turkey, Kurdish political groups took part in socialist parties. Political turmoil and violence between radical leftist and rightist political groups in 1970 changed Kurdish politics in Turkey. Since the establishment of the Republic, the military and civilian elite have seen the Kurds as the most serious potential danger. All expressions of Kurdish cultural identity were banned. The Kurds began to organize themselves separately through their own political parties.

The Kurdish Workers Party (PKK) was established by Abdullah Ocalan in 1978. The organization adopted a communist ideology, but later the aim of the organization was committed to the foundation of an independent Kurdish state in south-eastern Turkey and Syria (Teymur \& Cindy, 2008). Abdullah Öcalan founded PKK in 1977. PKK differed from other Kurdish political groups and benefited from political anarchy and turmoil in the late 1970s. The 1980 coup abolished human rights and denied the existence of a separate ethnic Kurdish group in Turkey so, this made Kurds feel upset. PKK started attacking Turkish military and police in the Eastern Turkey and they challenged Turkish sovereignty. Turkey’s reaction was fierce and military operations began like in the past.

Kemalist national identity in Turkey did not change to reduce the violence of PKK.

The PKK has won little popular among Kurds because of violent actions. PKK often changes tactics and attacks Turkish soldiers to declare international community that they struggle for independence and they only challenged the Turkish army instead civilians. Therefore, they try to make themselves known by mainstream media to announce the world that there is a serious Kurdish problem which is political not military (Strozier \& Frank, 2011). May be today the authorities will have to make decisions for peace in the country through expansion of Kurdish for all ethnic groups of Turkey.

Today, PKK still wants to continue terrorist attacks against Turkish soldiers and they kill many soldiers to show that by terrorism they can solve the Kurdish people. Here, the present authorities of republican Turkey, both civil and martial, must see that if the state can succeed to establish democratic links and to establish social, political and cultural steps in the Eastern part of Turkey, PKK will not be able to manipulate the Kurdish people announcing them the weak political sides of the state both financial and cultural.

To abolish the problem of PKK, it is not a good way to ban and close down the Kurdish parties officially by the Supreme Court. So far the official rule closed a few Kurdish parties, DTP (Democratic Society party) was just closed down in 2009, could we say that this helped to solve the Kurdish problem? As soon as the Kurdish parties were closed down; the Kurdish politicians established a new Kurdish party changing its name. For example, they continued their political life under the name of BDP (Peace and Democratic Party), so there is no doubt that closing down the parties and banning group rights such as language and education is not a final solution. It is obvious that when people are oppressed they feel more ambitious to struggle for their own rights without caring military precautions (Semiz, 2007). Just after BDP was closed down, the Kurdish politicians established the Peoples' Democratic Party (HDP) and they now continue their political life under the name of HDP. They might be daily solutions for the official authorities but anyhow in the near future the country might 
meet same problems soon as it happened after the coup of 1980. Sure, some Kurdish people can argue that PKK represents for all Kurdish people but it is clear that majority of the Kurdish people want to continue their life living in democratic republican Turkey. So, the authorities had better make new laws that will help every ethnic and minority group feel as if they live in their own countries.

After AK Party came to power, the new government tried to connect all interested parties to solve the Kurdish problem and started resolution process in 2013. The President Erdogan started the process stating that he would drink even hemlock poison to end the conflict in the Eastern part of Turkey. It is obvious that during AK Party governments Kurds have obtained many political and cultural rights in Turkey. Unfortunately when the peace process under the name of Resolution Process started PKK used it as an opportunity and piled up weapons burying in the grounds for a battle of the trench with Turkish soldiers. That means PKK did not care about peace and Kurdish problem but they only cared about taking advantage of civil war in Syria to establish a PKK state. Therefore PKK leaders used HDP as an instrument in Turkey and even HDP members supported the bombings of PKK in different parts of Turkey, even tens of civilians died in these armed attacks.

Today, Turkish Special Forces carry out many organizations in the region and killing hundreds of PKK terrorists. As mentioned above it is not enough to use only guns to stop terrorism but as PKK never stops using guns as the AK Party government insisted before it seems that there is no other way to consider. It is obvious that the President Erdogan, even in his last visit to a village in Diyarbakır to express condolence for the victims of PKK. It was the latest example in the Durumlu village in Diyarbakir, and PKK killed 16 civilians by a massive explosion. The size of the crater suggested the explosive was nitrate based and enhanced with about 15 tons of C3, a plastic explosive. Even though it was a big tragedy the mainstream media in Europe and US never mentioned about the tragic event but Erdogan declared that Turkey was ready to negotiate with the interested parties as soon as they took away their weapons.

However, the HDP delegitimized itself by not distancing itself from the PKK and not criticizing its terrorist attacks. Furthermore, people in the region were disappointed by the actions of the HDP municipalities, such as declaring self-government and digging ditches along major roads (Yavuz \& Özcan, 2015: pp. 81-82). Also the PKK has changed its tactics because of their current advantages in Syria. In Syria, the PKK has become the most reliable military partner of the US in operations against ISIL through its Syrian extension, the US-supported Democratic Union Party (PYD) (Bayraktar, 2009). Sometimes the US declares that the People's Defense Units (YPG), which is America's new friend, is not a terrorist organization and even urges Turkey to stop bombing the YPG in Syria.

It is not surprising that if Turkey continues to become more involved in Syria, it can cause indirect clash with the US who supports the PYD on the ground against ISIL (The Islamic State of Iraq and Levant). Here Turkey had better know how the US refused to support it during Cyprus problem in 1964 (Harris, 1972: p. 115). In addition, NATO never guarantees Turkey to support in Syria not to clash with Russia. By the way, the recent Russian-Assad agreement put them in a stronger position. As soon as the Syrian war ends, Turkey will be the most powerful country in the region since Turkey is the best alternative for the Kurds in Syria like in Iraq. That's why Turkey must avoid confronting any country in the region particularly Russia for the future positive outcomes.

As well known, without solving Kurdish problem Turkey cannot continue its progress. After the negotiations the solution process that is Kurdish-Turkish peace process started to end to armed struggle in 2013. PKK also announced that they would obey the solution through peace. However, in June 2015 both YPG and HDP accused Turkey of supporting ISIL soldiers to attack the Kurdish city of Kobani in Syria and that was a milestone for the process, because just after the following the PKK's unilateral decision the cease-fire ended. According to Gunter the PKK and PYD, with their strongly centralized leadership represent anything but advocates for locally based administration (Gunter, 2014). Indeed, it was not true that Turkey was supporting ISIL because Turkey allowed all Kurdish soldiers even from North Iraq to pass by Turkish borders to fight against ISIL in Kobani. The reason why the PKK made false statements was because they wanted to change tactics when they got advantages in Syria (Montgomery, 2005). After the collapse of ceasefire, violence spread throughout Turkey and hundreds of civilians and thousands of PKK militants were killed in the eastern part of Turkey.

\section{Conclusion}

Officially, Turkey makes no distinction between the YPG and the PKK despite the US-YPG partnership in Syria. The PYD in Syria seems a threat to Turkish security especially just after the collapse of a ceasefire. As PYD fo- 
cuses on Syria they may not prefer to open another front against Turkey. PKK-YPG cooperation suggests similar political ambitions in Turkey as in Syria, so it is disturbing for Turkey. That's why the future of the PKK problem depends on how the PKK approaches its demands in Turkey.

The PKK leadership refuses to return to peace talks unless the Turkish government accepts their demand for democratic autonomy as the PYD demands in Syria. It is clear now that the YPG expands its territory challenging Turkish interests in northern Syria. So the relationship between the PKK and PYD poses a serious problem for Turkish interests in Syria. In this regard, the US now has to decide whether Turkey or PYD their ally considering their long term interests in the region.

On the other hand, Turkey must find alternative ways to solve PKK problem, otherwise, Turkey cannot be a regional power with its long-term domestic problems; therefore it is vital to sort out its ethnical problems. Sure Iran and Iraq also have Kurdish problem but Turkey is a republican state and it may be a role model for the Middle East countries respecting all ethnic groups in its country being more sensitive. Most of the Kurds in Turkey want to live at peace so it is high time Turkey gave individual and group rights.

In conclusion, the political authorities in Turkey have better considered that whenever Turkey hugs all ethnic groups, undoubtedly it will be one of the most developed countries. It is clear that without solving its ethnical problems Turkey cannot become a regional power since it is not easy to establish a deep democracy with permanent national or international problems that remain unsolved. It is also crucial for the international community to describe the exact global meaning of terrorist since it causes uncertainty as in the example of PYD; for Turkey it is a terrorist organization however for the US it is a well partnership on the ground to struggle against ISIL in Syria. So if there is a common meaning of terrorist, it will be easy to deal with terrorism in the world.

\section{References}

Ahmad, F. (1993). The Making of Modern Turkey. New York: Routledge. http://dx.doi.org/10.4324/9780203418048

Ahmad. F., \& Yavuz, N. (2013). Ittihadve Terakki. Istanbul: Kaynak Yayinlari.

Bayraktar, M. (2009). Batinin Kanatlari Altinda PKK. Istanbul: Toplumsal Donusum Yayinlari.

Gunter, M. M. (1990). The Kurds in Turkey: A Political Dilemma. Westview: Boulder CO.

Gunter, M. M. (2014). Out of Nowhere: The Kurds in Syria in Peace and War. London: Hurst Publisher.

Hanioğlu, M. S. (1995). The Young Turks in Opposition. New York: Oxford University Press.

Hanioğlu, M. S. (2001). Preparation for a Revolution: The Young Turks, 1902-1908. New York: Oxford University Press.

Harris, G. S. (1972). Troubled Alliance: Turkish-American Problems in Historical Perspective, 1945-1971. Washington: American Enterprise Institute for Public Policy Research.

Kreyenbroek, P., \& Sperl, S. (1992). The Kurds: A Contemporary Overview. New York: Routledge.

McDowall, D. (2005). A Modern History of the Kurds. London: I. B. Tauris.

Montgomery, H. (2005). The Kurds of Syria: An Existence Denied. Berlin: S.n.

Russell, J. (2012). Kurds in Turkey. Amazon.co.uk

Semiz, B. (2007). Çıkmaz Sokak: PKK: PKK Dag Kadrosunun Metodolojisive Sosyolojisi. Ankara: Lalezar Kitabevi.

Strozier, C. B., \& Frank, J. (2011). The PKK Financial Sources, Social and Political Dimensions. Saarbrucken: VDM Verlag Dr Muller.

Teymur, S., \& Cindy, J. S. (2008). The PKK: A Decades-Old Brutal Marxist-Leninist Separatist Terrorist Organization. Washington: Turkish Institute for Security and Democracy.

White, P. J. (2015). The PKK: Coming down from the Mountains. London: Zed.

Yavuz, M. H., \& Özcan, N. A. (2015). Turkish Democracy and the Kurdish Question. Middle East Policy, $22,73-87$. http://dx.doi.org/10.1111/mepo.12159

Yildiz, K. (2005). The Kurds in Turkey: EU Accession and Human Rights. London: Pluto in Association with Kurdish Human Rights Project.

Zurcher, E. J. (1993). Turkey: A Modern History. London: I.B. Tauris. 


\section{Submit or recommend next manuscript to SCIRP and we will provide best service for you:}

Accepting pre-submission inquiries through Email, Facebook, LinkedIn, Twitter, etc.

A wide selection of journals (inclusive of 9 subjects, more than 200 journals)

Providing 24-hour high-quality service

User-friendly online submission system

Fair and swift peer-review system

Efficient typesetting and proofreading procedure

Display of the result of downloads and visits, as well as the number of cited articles

Maximum dissemination of your research work

Submit your manuscript at: http://papersubmission.scirp.org/ 